\section{Musical Sands.}

IN an interesting letter Mr. Carus-Wilson gives us the results (NATURE, July 15) of further observations made by him on a phenomenon on which he has written from time to time. I believe I have suggested to him in years gone by-if not, perhaps you will allow me to suggest now-the possibility of the musical ring of certain sands in motion being due to their consisting largely of grains of hyaline quartz. That fact, if ascertained, would account for the ring of the grains in motion, while the smoothness of their glassy surfaces would facilitate their motion, and so increase the force of their mutual impact, tending to raise the pitch of the note produced. I have never had an opportunity myself of making a microscopic examination of such sands, but I venture to commend such an examination to Mr. Carus-Wilson's consideration. The assortment of the sands by the wind into possibly more rounded and more angular grains may also throw some light upon the matter.

Bishop's Sțortford, July 19.

\section{Wych Elm Seedlings.}

THE prolific flowering of the Wych elm, Ulmus montana, this year must have been followed by the formation of unusual numbers of fertile seeds. At present the ground beneath these elms in my garden is covered with hundreds of their seedlings, many of which have already developed a second pair of serrated leaves.

The elms themselves seem to have suffered from the strain of producing so large a crop of fruits, for their leaves, though now of the usual size, were very late in appearing, and are sparsely distributed on the branches.

26 Blessington Road, Lee, Kent, July i3.

\title{
POPULAR NATURAL HISTORY.
}

MR. LEA'S " Romance of Bird-life," " a handy and $M$ fully illustrated volume published at a marvellously low price, covers the whole life-history of the bird, from the egg upwards, the twenty-one chapters containing a summary of the observations of a great many writers on ornithology arranged in a masterly and most attractive form. One of the concluding " chapters deals with the birds of the past and vanishing species, and is illustrated with a reproduction of a curious old wood-cut published in 1601 , representing early voyagers knocking down dodos and other birds with sticks on the island of Mauritius. In that upon "Wisdom and Folly" we have anecdotes bearing on the intellectual capacity of birds. There are many instructive passages in the book, which is quite a mine of information. It is stated that in more than one instance, if when a chick was cheeping while still in the sheil the mother uttered a note of warning, the cheeping stopped instantly; and it is pointed out that this teaches us that the simple language of call-notes is instinctive, for the chick cannot possibly have learnt their meaning by experience. Nestlings the food of which is placed in their mouths by their parents cannot be taught to pick it up from the ground like chicks until they are much older. Young moorhens, however, which are fed from their mother's beak at first, will peck upwards at anything that is offered to them, but not downwards. So far as the author is aware the frigate bird is the only species which ever carries on fishing in mid-air, waiting until the flying-fish are startled from the sea by some large fish which preys on them below the sur-

1 "The Romance of Bird Life." Being an Account of the Education, Courtship, Snort and Play, Journeys, Fishing, Fighting, Piracy, Domestic and Social Habitc, Instinct, Strange Friendships and other interesting Aspects of the Life of Birds." By John Lea. Pp. 376; illustrated. (London: Seeley and Co., Ltd., 1909.) Price $5 s$. No. 2073 , VOL. 81 ]

face; other fishing birds follow them into the water. The romantic story of the ospreys at loch-en-eilein (which should be written eilean) is told and illustrated. Possibly the "romance" is a little overstrained in places, and ordinary incidents in a bird's general life habits sometimes magnified or transfigured into something more wonderful. For instance, it is a common custom with snow buntings (and with some other quick-footed birds which feed in flocks) for the rear ranks to fly to the front over the backs of the others, a manœuvre repeated by the others in turn. This simple desire (and its expression) to have first turn at whatever food is going is here advanced as " a boisterous little game of their own " in the section on sport and play. The combats of ruffs are much milder and much less important affairs than is here represented; and it seems really unlikely that nuthatches could drive out squirrels from their nest, or would want to take possession of it. Unlike most of the popular bird books published in recent years this one fills a vacant place.

Almost anyone seems to feel capable nowadays of writing a book on British birds, and, in good truth, there is material enough to compile from. Time was when to write an account of British birds was an undertaking attempted by tew, and those only who had made the subject their main study for many years, and were on all hands accounted authorities. Now almost anyone does it, and there is a perfect stream of books on this subject. They come out so frequently that, although the title has been turned and twisted in a great variety of ways, it has even been found impossible to discover fresh and original names to distinguish them by. Most of them put forward some special claim upon the public. Many of them purport to cater for the ignorant and the beginner; one, indeed, made a point of picking brains without acknowledgment. Here is one " with a new method of identification." This book has been written with the exclusively practical object of enabling persons unacquainted with British birds to identify them by their most obvious characteristics. By the grouping of birds, as here carried out, under such headings as " Black-and-White Birds," " Ruddy-breasted Birds," "Trunk-climbing Birds," it is claimed that the birds are presented to the beginner as he himself sees them. Where necessary, notes are appended to the descriptions indicating those birds with which the one described is most likely to be confounded, and the chief characteristics by which it is to be distinguished from them. Before proceeding to observe birds, however, the user of this book need do no more than read through the list of group-headings. The book is, in fact, another attempt at a royal road to a knowledge of our birds. The idea has been tried over and over again in some shape or form, both here and in America, but we do not think it will ever be successful. In the present case the difficulties of grouping begin to be apparent very shortly. "Skuas" as a group heading will convey nothing to the beginner without good pictures. In the end the author is left with three birds, the jay, the goldfinch, and the white wagtail, which do not fall into any groups. The two first are so conspicuous that perhaps they do not want grouping; but, really, after some of the grouping, e.g. putting the hedge sparrow and some others among those which are "brown above and white below," it seems rather like straining at a gnat not to have dropped the third in among the black-and-white birds. We are glad to read that there are a few breeding pairs of kites in the Midlands of England, and hope

1 "British Birds and their Eggs, with a New Method of Identification." By J. Maclair Boraston. Pp. $x+30 x ; i_{3} 6$ coloured illustrations. (London and Edinburgh: W. and R. Chambers, 1909.) Price 6s. net. 